\title{
SISTEM INFORMASI COMPANY PROFILE PT. SINAR NUSANTARA SAKTI MENGGUNAKAN WORDPRESS
}

\author{
Mirhan Siregar ${ }^{1}$, Nilam Kusumawati ${ }^{2}$, Asmira $^{3}$, Aris Susanto ${ }^{4}$ \\ ${ }^{1}$ anggiku07@gmail.com, ${ }^{2}$ nilamkusumawati82@gmail.com, \\ 3asmira@stmikbinsa.ac.id, ${ }^{4}$ arissusantoh@gmail.com \\ ${ }^{1,3,4}$ STIMIK Bina Bangsa, ${ }^{2}$ AMIK Yapenas Kendari
}

\begin{abstract}
Abstrak
Informasi profil perusahaan yang disampaikan melalui media website dapat tersampaikan dengan cepat dan menjangkau keseluruh dunia, mengingat website dapat diakses secara global. Dengan adanya website company profil, informasi perusahaan dapat dilihat masyarakat luas sehingga dapat meningkatkan kredibilitas perusahaan. Penelitian ini bertujuan untuk mengembangkan sistem informasi company profil PT. Sinar Nusantara Sakti menggunakan Content Management System berbasis Wordpress. Metode yang digunakan yaitu studi literatur, pengumpulan data, perancangan sistem, dan implementasi. Hasil pengembangan produk yang dilakukan diperoleh sistem informasi company profil berbasis web yang dapat digunakan untuk menyampaikan informasi perusahaan secara efektif dan efisien.
\end{abstract}

Kata kunci: Sistem Informasi, Company Profile, Website, Wordpress

Abstract
Company profile information conveyed through website media can be conveyed quickly and reach the whole world, considering that the website can be accessed globally. With the company profile website, company information can be seen by the wider community so that it can increase the company's credibility. This study aims to develop a company profile information system for PT. Sinar Nusantara Sakti using a Wordpress-based Content Management System. The method used is literature study, data collection, system design, and implementation. The results of product development carried out are obtained by a web-based company profile information system that can be used to convey company information effectively and efficiently.

Keywords: Information Systems, Company Profile, Website, Wordpress

\section{Pendahuluan}

Era modern saat ini, penyebaran informasi dapat dilakukan sangat cepat diseluruh dunia melalui berbagai Teknologi Informasi. Berbeda dengan penyebaran informasi di era sebelumnya penyebaran informasi dapat dilakukan melalui media cetak seperti surat kabar, spanduk, dan brosur. Namun, penyebaran informasi melalui media cetak memerlukan biaya yang cukup besar, waktu yang digunakan untuk mengolah informasi lambat, dan penyampaian informasinya sangat terbatas.

Kelemahan media cetak dari segi biaya yang cukup besar dan membutuhkan waktu yang lama dalam menyampaikan informasi serta memiliki jangkaun yang terbatas. Hal ini, menjadi permasalahan disetiap perusahaan untuk mempromosikan perusahannya kepada masyarakat termasuk PT. Sinar Nusantara Sakti.

Sinar Nusantara Sakti merupakan perusahaan yang bergerak dibidang management development dan memiliki visi menciptakan Kawasan Industri Konawe Utara (KIKU) yang modern di Wilayah Indonesia Bagian Timur. Perusahaan tersebut berdiri pada Tahun 2017 dengan nomor izin AHU0022857.AH.01.01.Tahun 2017 yang didirikan oleh Ahmad Sucipto sekaligus sebagai direktur utama perusahaan tersebut. Informasi yang diperoleh dari pimpinan perusahaan bahwa kendala yang dihadapi adalah minimnya media yang digunakan untuk menampilkan profil perusahaan kepada pemerintah dan masyarakat secara cepat dengan biaya yang terbatas. Oleh karena itu, solusi yang ditawarkan adalah 
Jurnal Sistem Informasi dan Sistem Komputer,Vol.6, No.1, Januari 2021

ISSN: 2715-906X (Online)

d $10.51717 /$ simkom.v6i1.54

membuat profil perusahaan berbasis web. Profil perusahaan atau biasa disebut company profile merupakan informasi penting suatu perusahaan untuk menjalin hubungan antar perusahaan dan instansi terkait lainnya.

Profil perusahaan yang disampaikan melalui media website tentu dapat tersampaikan secara cepat dengan biaya yang sedikit dan menjangkau keseluruh dunia, mengingat website dapat diakses secara global. Dengan adanya website company profile, informasi terkait perusahaan dapat dilihat oleh masyarakat sehingga dapat meningkatkan kredibilitas perusahaan. Beberapa penelitian sebelumnya pernah dilakukan untuk membangun sebuah company profile seperti penelitian tentang website company profile sebagai media promosi [1], rancang bangun website company profile [2][3], website company profile menggunakan wordpress [4].

Membangun sebuah website company profile diperlukan sebuah tools seperti bahasa pemrograman dan aplikasi design untuk menghasilkan interface yang menarik. Selain itu, dibutuhkan sebuah pemahaman terhadap penggunaan tools tersebut. Mengingat tidak semua orang dapat melakukan pemrograman dan menggunakan aplikasi design untuk membangun sebuah website. Maka, solusi yang digunakan dalam penelitian ini adalah menggunakan aplikasi Content Management System (CMS) untuk mengelolah website. Salah satu CMS yang terkenal dan familiar dikalangan pengembang website adalah Wordpress.

Wordpress merupakan Content Management System yang sangat mudah digunakan untuk mengelolah sebuah website company profile. Hal ini, dapat dilakukan oleh semua orang tanpa perlu memahami bahasa pemrograman. Aplikasi tersebut sangat mudah digunakan hanya dengan mengelolah content sehingga tidak diperlukan pemahaman tentang pemrograman.

Sebagai upaya untuk memudahkan perusahaan menampilkan profil perusahaan agar dapat dikenal secara global serta dapat meningkatkan kredibilitas perusahaan. Maka, dikembangkan Sistem Informasi Company Profile PT. Sinar Nusantara Sakti Berbasis Web Menggunakan Wordpress.

\section{Landasan Teori}

\subsection{Sistem Informasi}

Sistem berasal dari bahasa latin (systema) dan bahasa Yunani (sustema) adalah suatu kesatuan yang terdiri komponen atau elemen yang di hubungkan bersama untuk memudahkan informasi, materi atau energi untuk mencapai suatu tujuan. Suatu prosedur adalah urutan-urutan yang tepat dari tahapan-tahapan instruksi yang menerangkan apa (what) yang harus dikerjakan, siapa (who) yang mengerjakannya, kapan (when) dikerjakan dan bagaimana (how) mengerjakannya. Subsistem-subsistem dalam suatu sistem saling berinteraksi, saling berhubungan membentuk suatu kesatuan sehingga tujuan sistem tersebut dapat tercapai [5].

Sistem adalah suatu jaringan kerja dari prosedur-prosedur yang saling berhubungan, berkumpul bersama-sama untuk melakukan suatu kegiatan atau penyelesaian suatu sasaran tertentu [6]. Selanjutnya sistem di definisikan dengan pendekatan prosedur dan dengan pendekatan komponen. Dengan pendekatan prosedur, sistem dapat di definisikan sebagai kumpulan dari prosedur-prosedur yang mempunyai tujuan tertentu. Contoh sistem yang didefinisikan dengan pendekatan ini adalah sistem akuntansi. Sistem ini di definisikan sebagai kumpulan dari prosedurprosedur penerimaan kas, pengeluaran kas, penjualan, dan pembelian dan buku besar [7]. Sistem juga didefinisikan sebagai kumpulan element yang saling berhubungan dan berinteraksi dalam satu kesatuan untuk menjalankan proses pencapaian suatu tujuan utama [8].

Sumber dari informasi adalah data. Data adalah representasi fakta dunia nyata yang mewakili suatu objek seperti manusia (pegawai, siswa, pembeli, pelanggan), barang, hewan, peristiwa, konsep, dan keadaan yang di wujudkan dalam bentuk angka, huruf, symbol, teks, gambar, bunyi, atau kombinasinya [9]. Sedangkan informasi adalah kumpulan data yang di olah menjadi bentuk yang lebih berguna dan lebih berarti bagi yang menerima [8]. Selanjutnya informasi di 
Jurnal Sistem Informasi dan Sistem Komputer,Vol.6, No.1, Januari 2021

ISSN: 2715-906X (Online)

\section{doi) $10.51717 /$ simkom.v6i1.54}

definisikan sebagai kumpulan fakta (data) yang diorganisasikan dengan cara tertentu sehingga mereka mempunyai arti bagi penerima [10]. Informasi yang berkualitas tentu akan membantu fungsional manajemen dalam megambil keputusan organisasi dalam mengambil keputusan organisasi. Informasi internal dan eksternal harus lebih berkualitas, sebagai ukuran kualitas informasi yaitu akurat, relevan dan tepat waktu.

Suatu proses pengolahan data menjadi sebuah informasi terdiri dari 3 tahapan dasar, yang di sebut dengan siklus pengolahan data (data processing cycle), yaitu input, processing dan output [11]

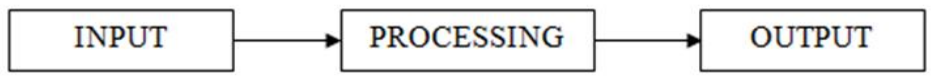

Gambar 1. Siklus Pengolahan Data

Sistem informasi merupakan suatu komponen yang terdiri dari manusia, teknologi informasi, dan prosedur kerja yang memproses, menyimpan, menganalisis, dan menyebarkan informasi untuk mencapai suatu tujuan [12]. Selanjutnya sistem informasi didefinisikan sebagai sistem yang dapat di definisikan dengan mengumpulkan, memproses, menyimpan, menganalisis, menyebarkan informasi untuk tujuan tertentu. Seperti sistem lainnya, sebuah sistem informasi terdiri atas input, proses, dan output [10].

\subsection{Company Profile}

Company profile adalah sebuah aset suatu lembaga atau perusahaan yang dapat digunakan untuk meningkatkan suatu image atau citra dari perusahaan untuk menjalin kerja sama dengan relasi perusahaan, lembaga dan instansi yang terkait lainya [13]. Berikutnya company profile adalah sebuah aset suatu lembaga atau perusahaan yang biasa digunakan sebagai tanda pengenal dalam melakukan komunikasi baik dan kerjasama dalam lingkup intern perusahaan maupun dengan kolega, mitra usaha ataupun pihak-pihak terkait lainnya diluar lingkungan perusahaan tersebut [14].

\subsection{Website}

WWW atau World Wide Web maupun Web adalah sebuah sistem yang saling terkait dalam sebuah dokumen berformat hypertext yang berisi beragam informasi, baik tulisan, gambar, suara, video, dna informasi multimedia lainnya dan dapat di akses melalui sebuah perangkat yang disebut web browser. Sebuah website terdiri dari halaman-halaman yang dipublikasikan oleh web server. Salah satu atau beberapa elemen-elemen ini harus ada dalam sebuah halaman agar halaman web tersebut memiliki maksud dan arti tertentu. Elemen-elemen tersebut adalah segala sesuatu yang bisa kita lihat maupun dengar dalam sebuah halaman website diantaranya teks, gambar, hyperlink, audio dan video.

\subsection{Wordpress}

Wordpress adalah sebuah platform website yang bersifat open scource dan sangat popular. Wordpress digunakan sebagai mesin blog ataupun untuk platform yang bisa dimanfaatkan untuk membuat website multi fungsi dengan memanfaatkan berbagai plugins [15].

\section{Metode}

Metode pengumpulan data yang digunakan pada penelitian ini adalah metode studi literatur, observasi, dan wawancara. Studi literatur merupakan salah satu metode pengumpulan data yang dilakukan dengan cara membaca referensi berupa buku-buku atau jurnal penelitian. Observasi merupakan suatu metode pengumpulan data dengan mengadakan pengamatan secara langsung, 
Jurnal Sistem Informasi dan Sistem Komputer,Vol.6, No.1, Januari 2021

ISSN: 2715-906X (Online)

\subsection{7/simkom.v6i1.54}

cermat dan sistematis atas fenomena yang diteliti. Wawancara adalah pengambilan data yang dilakukan dengan cara melakukan tanya jawab secara langsung sambil bertatap muka antara pewawancara terhadap responden. Selanjutnya tahapan penelitian dibuat untuk memudahkan membaca penelitian yang dilaksanakan. Tahapan penelitian ini dirangkai dalam bentuk diagram alir sebagai berikut:

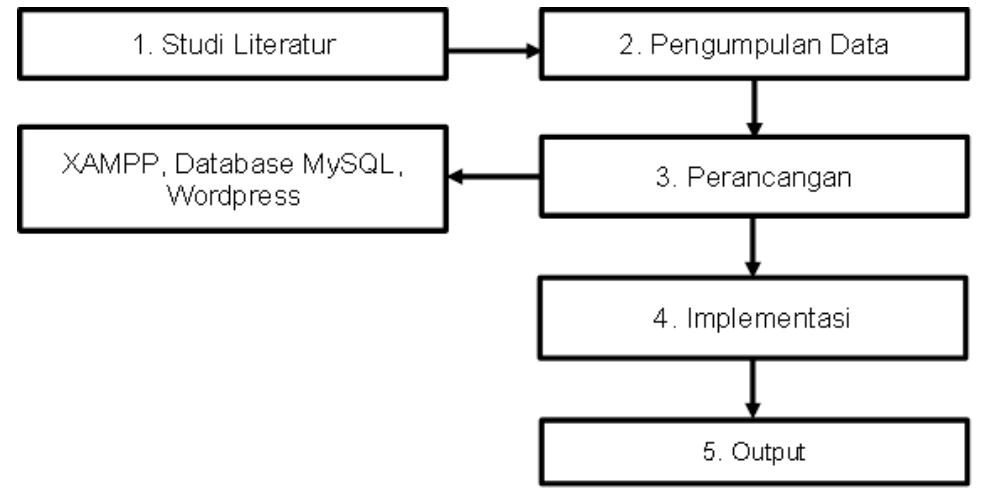

Gambar 2. Tahapan Penelitian

1) Studi Literatur

Pada tahapan ini dilakukan untuk mendapatkan referensi berupa teori dan penelitian yang relevan.

2) Pengumpulan Data

Tahapan ini merupakan proses pengumpulan data yang berkaitan dengan informasi data profile perusahaan.

3) Perancangan

Tahapan ini merupakan proses perancangan tampilan dan mengelola secara langsung konten berdasarkan data yang diperoleh dari hasil pengumpulan data.

4) Implementasi

Tahapan ini merupakan proses penerapan sistem dan melakukan pengujian terhadap sistem informasi company profile perusahaan.

5) Output

Pada tahapan ini dihasilkan sistem informasi company profile perusahaan PT. Sinar Nusantara Sakti.

\section{Hasil}

\subsection{Analisa Kebutuhan Sistem}

PT. Sinar Nusantara Sakti memiliki permasalahan dalam mengelola sistem informasi company profile sehingga lambat dalam menyebarkan informasi terkait dengan profil perusahaan. Oleh karena itu, dibutuhkan sebuah sistem yang dapat membantu dalam percepatan penyampaian informasi yang berhubungan dengan perusahaan sehingga dapat meningkatkan kredibilitas perusahaan serta dapat membantu dalam peningkatan kerjasama antar perusahaan. Selain itu, sumber daya manusia juga diperlukan untuk mengelola sistem tersebut sehingga tidak mudah bagi perusahaan untuk mengeluarkan biaya dalam pengelolaan sistem tersebut. Sehingga solusi yang dapat diberikan dalam penelitian ini adalah mengembangkan sistem informasi company profile berbasis Content Management System menggunakan Wordpress sehingga pihak perusahaan tidak perlu merekrut pegawai untuk mengelolah website tersebut dikarenakan sistem yang dikembangkan dalam penelitian sangat mudah dikelola untuk menyampaikan informasi terkait perusahaan. Sistem 
Jurnal Sistem Informasi dan Sistem Komputer,Vol.6, No.1, Januari 2021

ISSN: 2715-906X (Online)

\section{doi) $10.51717 /$ simkom.v6i1.54}

informasi company profile yang dikembangkan memiliki fitur antara lain: halaman awal yang berisi informasi sambutan direktur, rencana project, aspek pemasaran, team pengurus, dan kontak perusahaan. Data proloq, profil perusahaan berupa legalitas, visi misi, dan pengurus. Data project, peta kawasan industri dan lokasi, dan data gallery perusahaan.

\subsection{Perancangan Sistem}

Perancangan sistem merupakan penggambaran fungsionalitas dari suatu sistem. Berikut rancangan sistem informasi company profile PT. Sinar Nusantara Sakti.

1) Use Case Diagram

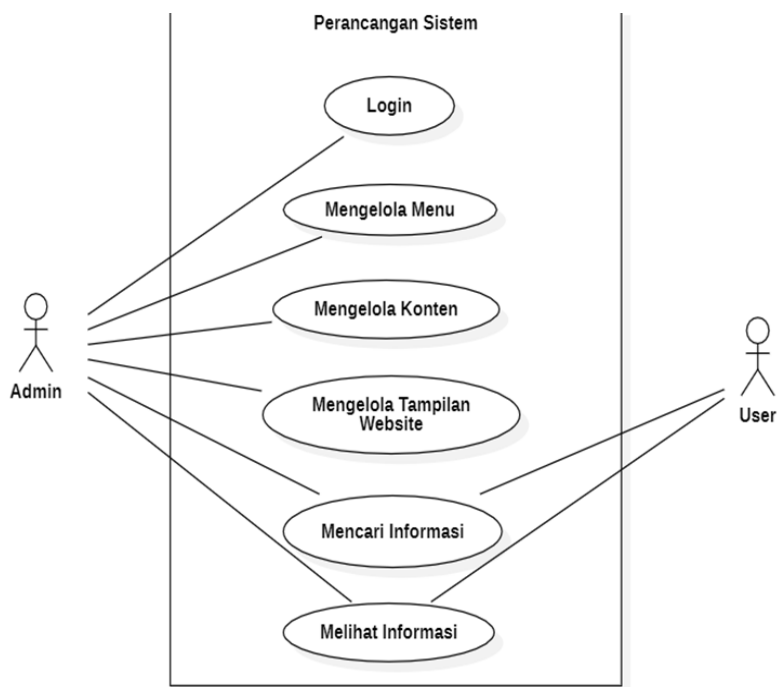

Gambar 3. Use Case Diagram

2) Flowchart Login

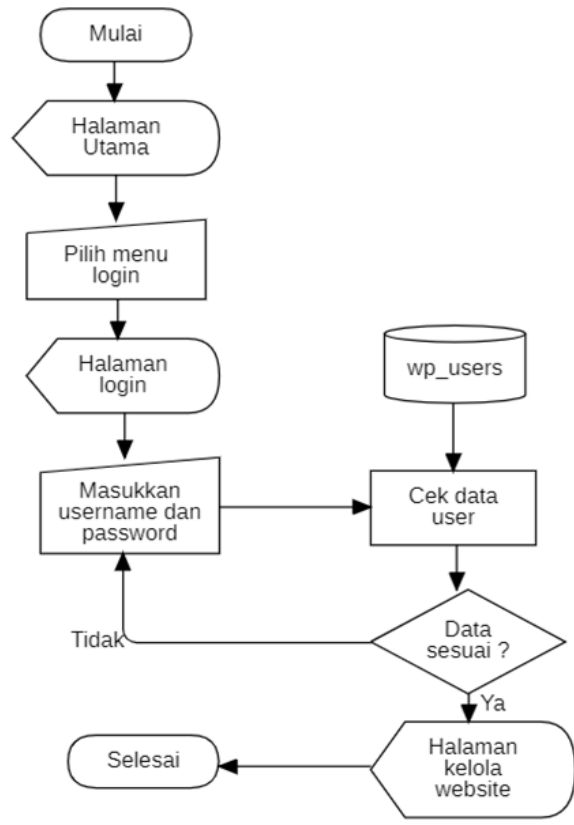

Gambar 4. Flowchart Login 
Jurnal Sistem Informasi dan Sistem Komputer,Vol.6, No.1, Januari 2021

ISSN: 2715-906X (Online)

doi $10.51717 /$ simkom.v6i1.54

3) Flowchart Tambah Artikel

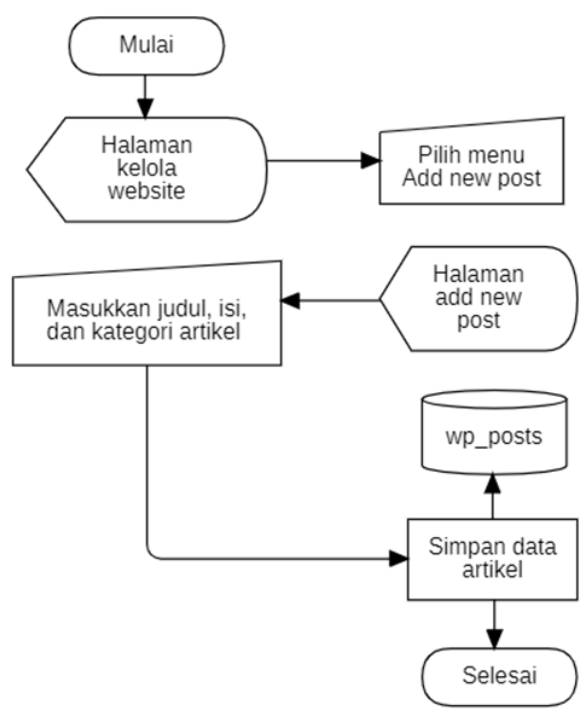

Gambar 5. Flowchart Tambah Artikel

4) Flowchart Menampilkan Artikel

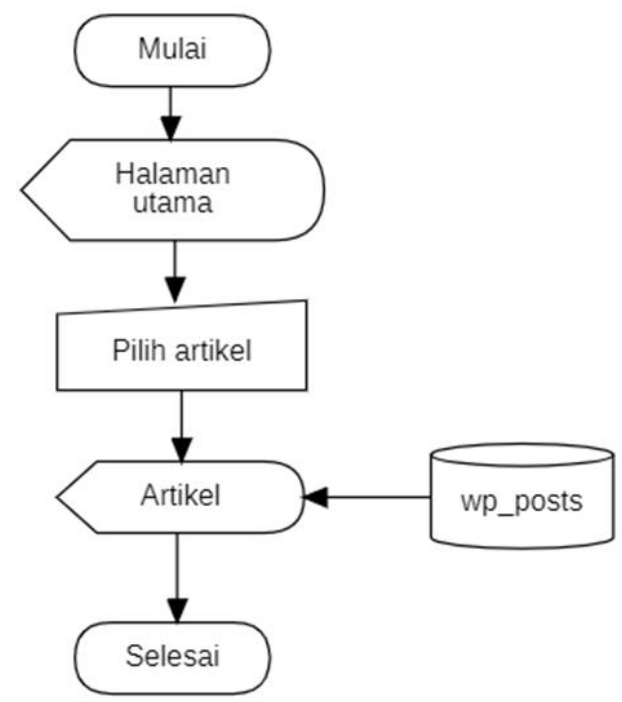

Gambar 6. Flowchart Menampilkan Artikel

5) Rancangan Interface

Rancangan interface terdiri dari logo yang merupakan identitas lembaga, navigasi berupa menu website yang terdiri dari menu beranda, proloq, profil, project, KIKU, galeri, dan kontak.. Selanjutnya slide merupakan bagian yang menampilkan gambar unggulan. Section berisi informasi umum tentang lembaga. Content merupakan bagian yang berisi informasi umum terkait kegiatan dan informasi penting perusahaan, dan footer merupakan bagian yang menampilkan catatan kaki pada website. 
Jurnal Sistem Informasi dan Sistem Komputer,Vol.6, No.1, Januari 2021

ISSN: 2715-906X (Online)

do) $10.51717 /$ simkom.v6i1.54

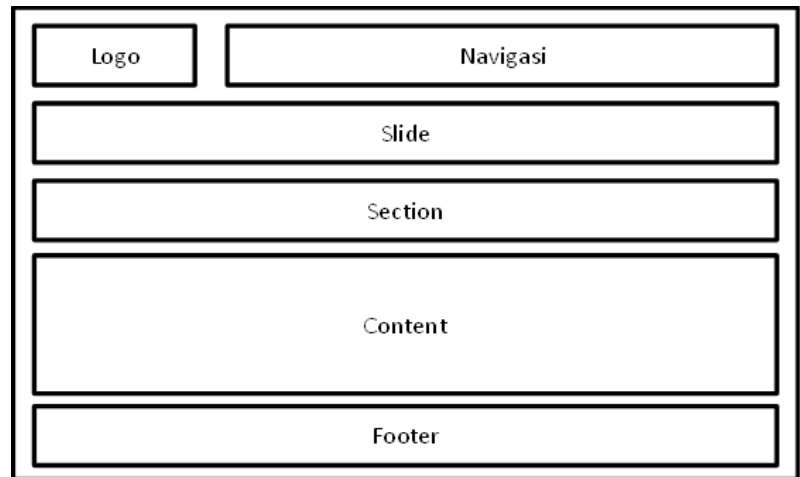

Gambar 7. Rancangan Interface

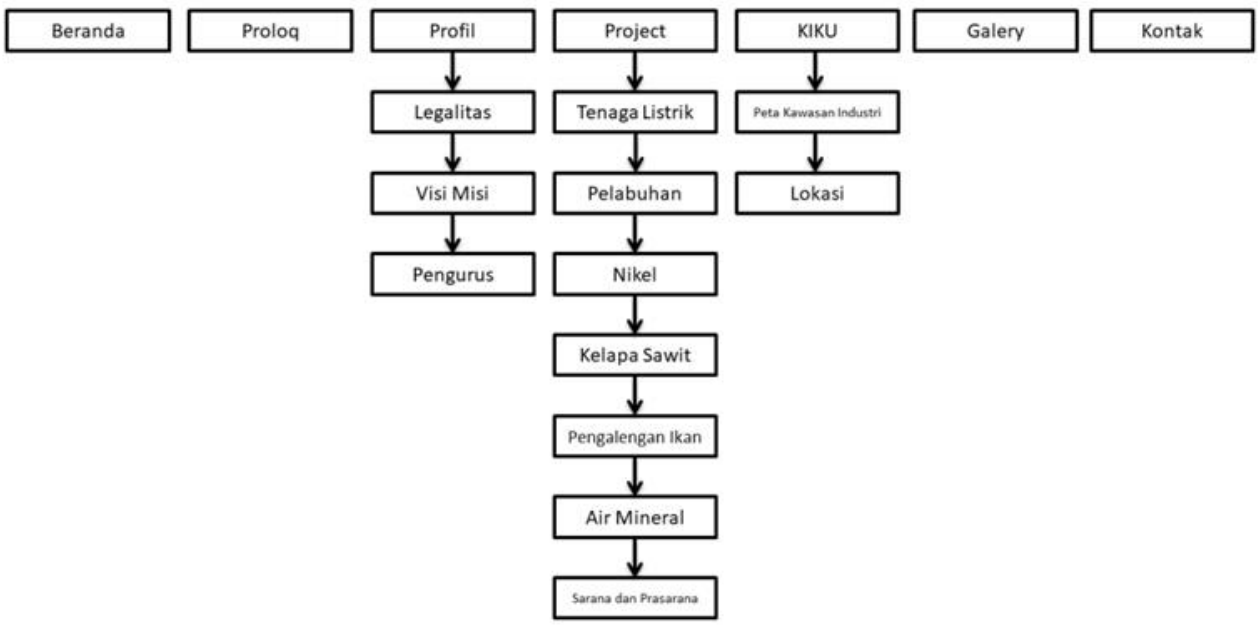

Gambar 8. Rancangan Struktur Menu

\subsection{Implementasi Sistem}

Hasil penelitian yang dilakukan, maka didapatlah sebuah Website Company Profil PT. Sinar Nusantara Sakti.

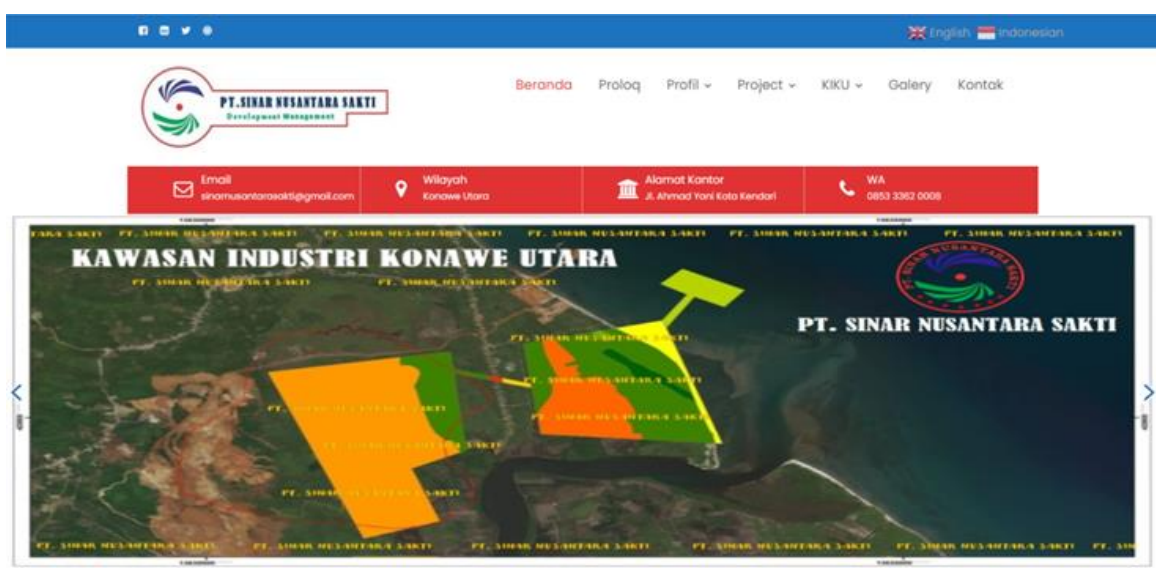

Gambar 9. Halaman Beranda 
Jurnal Sistem Informasi dan Sistem Komputer,Vol.6, No.1, Januari 2021

ISSN: 2715-906X (Online)

doi) $10.51717 /$ simkom.v6i1.54

Halaman beranda memuat informasi kontak perusahaan, gambar utama, sambutan direktur, rencana project, aspek pemasaran, tujuan perencanaan, team pengurus, dan gallery.
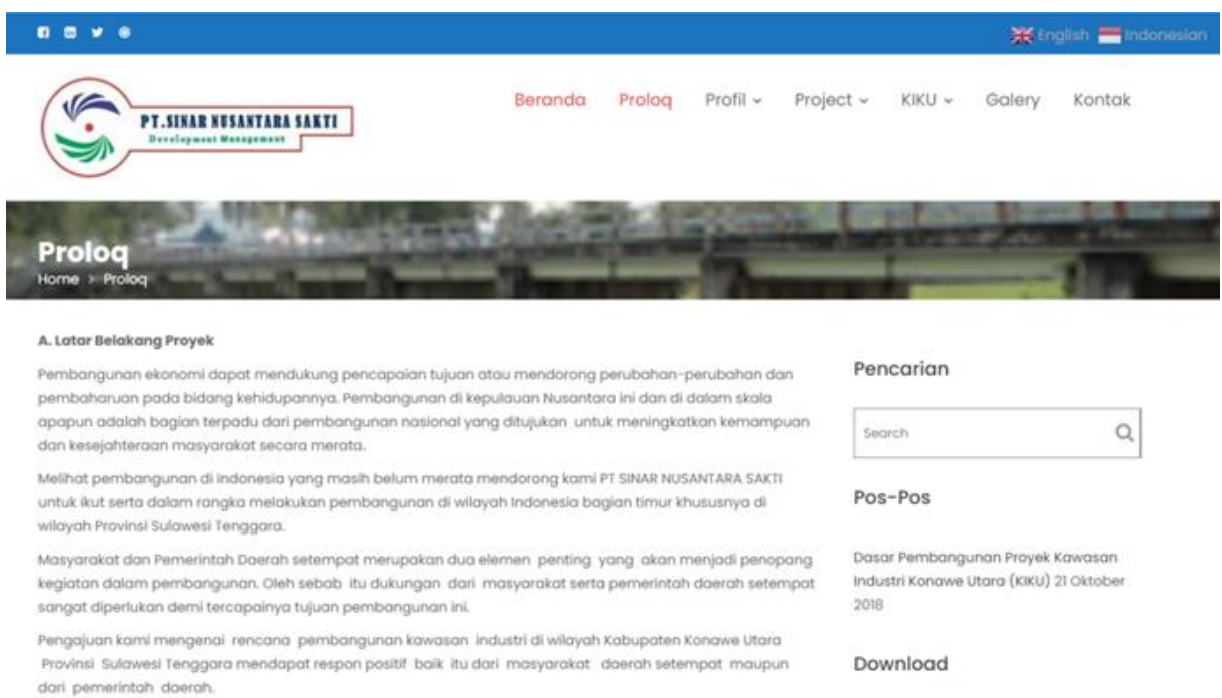

Pencarian

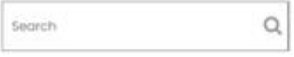

Pos-Pos

Dasat Pembangunan Proyek Kawasan

Industri Konawe utaro (Kkiu) 21 outobes

Download

Gambar 10. Halaman Proloq

Halaman proloq memuat informasi tentang latar belakang proyek, maksud dan tujuan, gambaran lokasi, batas wilayah, potensi sumber daya alam, dukungan masyarakat, ringkasan proyek, aspek pemasaran, tujuan perencanaan, dan deskripsi perusahaan.
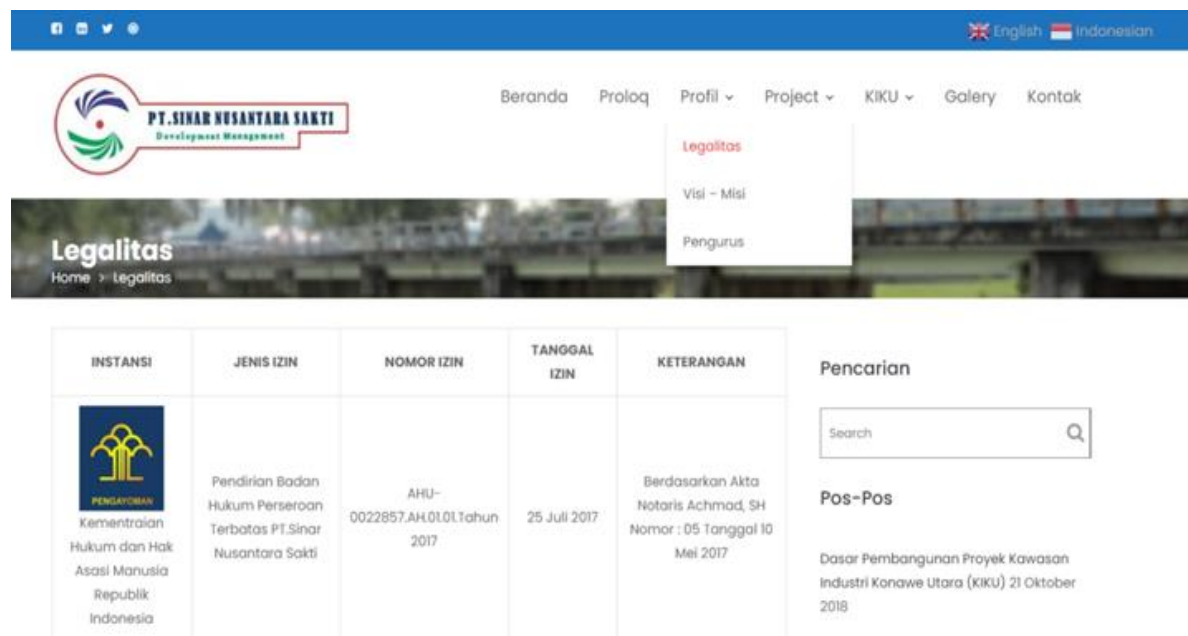

Gambar 11. Halaman Legalitas

Halaman legalitas memuat informasi tentang legalitas perusahaan yang diberikan oleh instansi, jenis izin, nomor izin, tanggal izin, dan keterangan. 
Jurnal Sistem Informasi dan Sistem Komputer,Vol.6, No.1, Januari 2021

ISSN: 2715-906X (Online)

doi) $10.51717 /$ simkom.v6i1.54

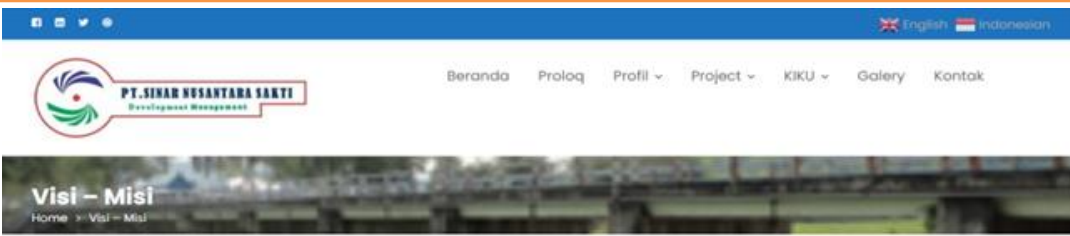

vial
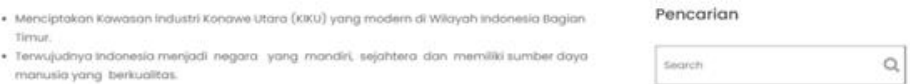

masi

Pos-Pos
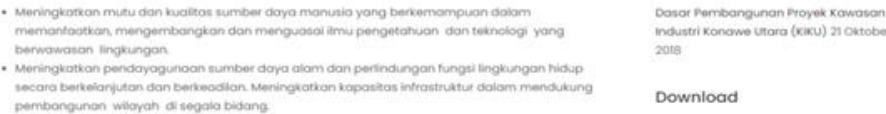

zots

Gambar 12. Halaman Visi Misi

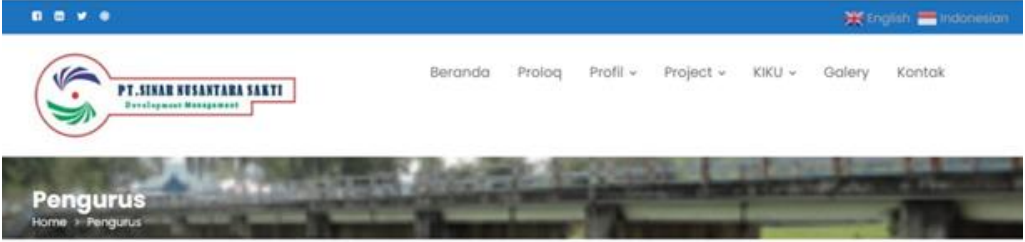

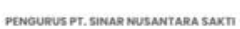
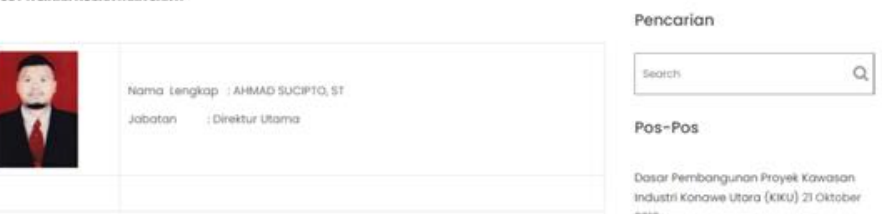

Gambar 13. Halaman Pengurus

Halaman pengurus memuat informasi tentang daptar pengurus perusahaan PT. Sinar Nusantara Sakti.

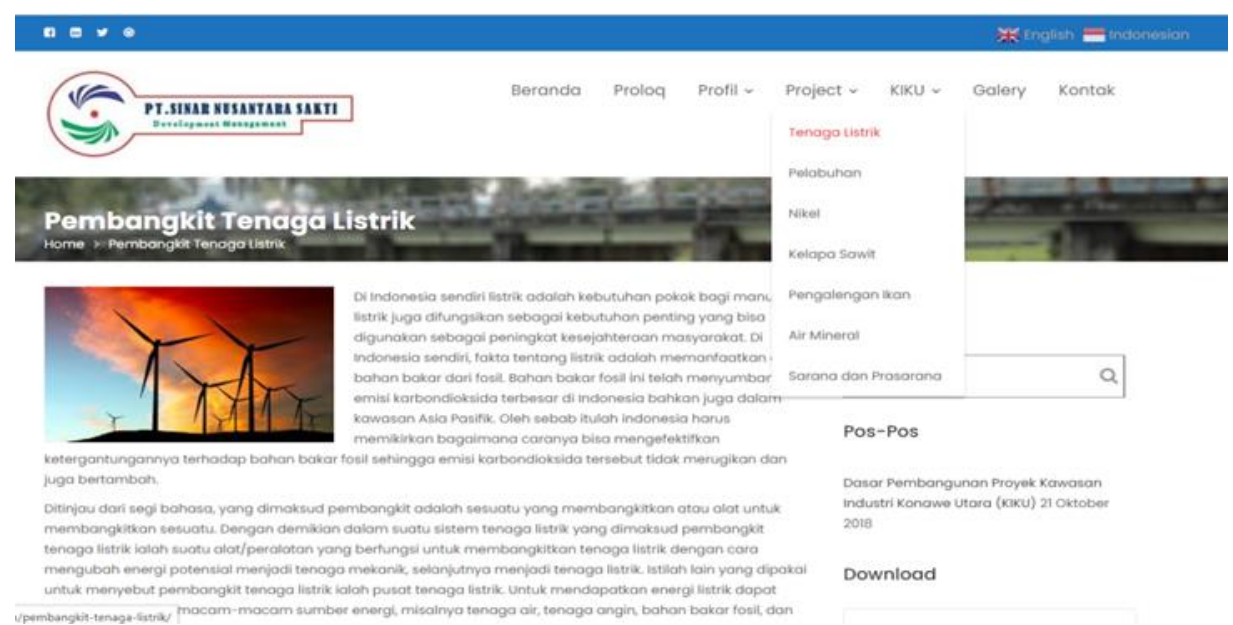

Gambar 14. Halaman Project

Halaman project memuat informasi tentang project perusahaan seperti: pembangkit tenaga listrik, pelabuhan, nikel, kelapa sawit, pengalengan ikan, air mineral, sarana dan prasarana. 
Jurnal Sistem Informasi dan Sistem Komputer,Vol.6, No.1, Januari 2021

ISSN: 2715-906X (Online)

doi) $10.51717 /$ simkom.v6i1.54
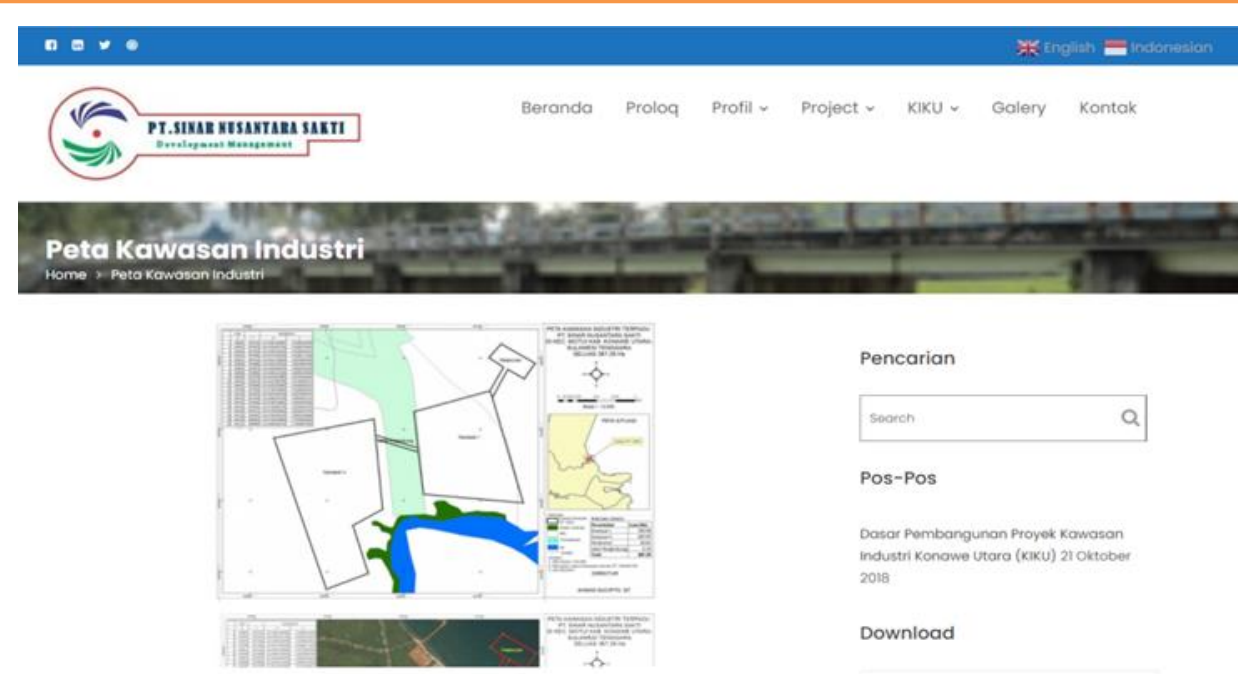

Gambar 15. Halaman Peta Kawasan Industri

Halaman ini memuat informasi perusahaan tentang peta Kawasan Industri Konawe Utara.
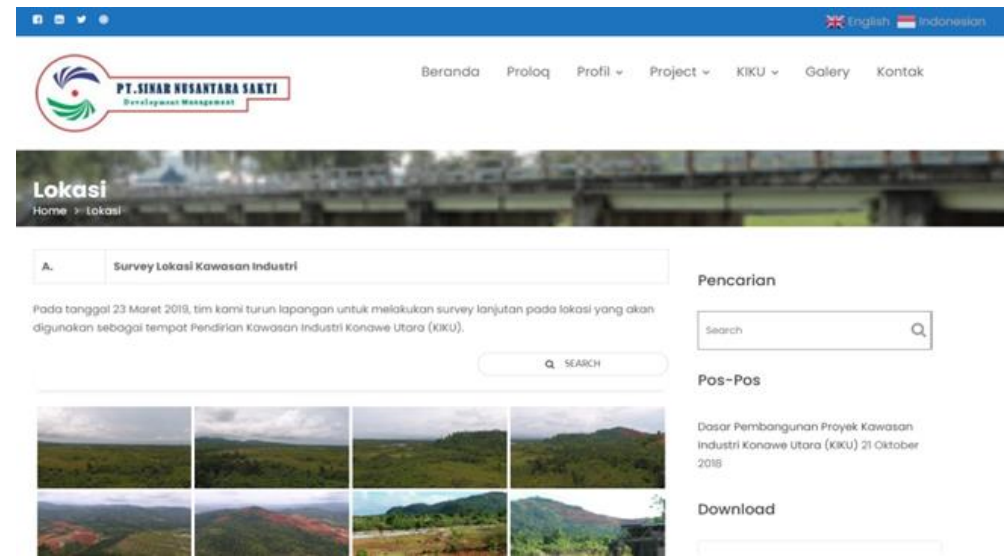

Gambar 16. Halaman Lokasi

Halaman ini memuat informasi tentang survey lokasi kawasan industri dan lokasi pelabuhan.
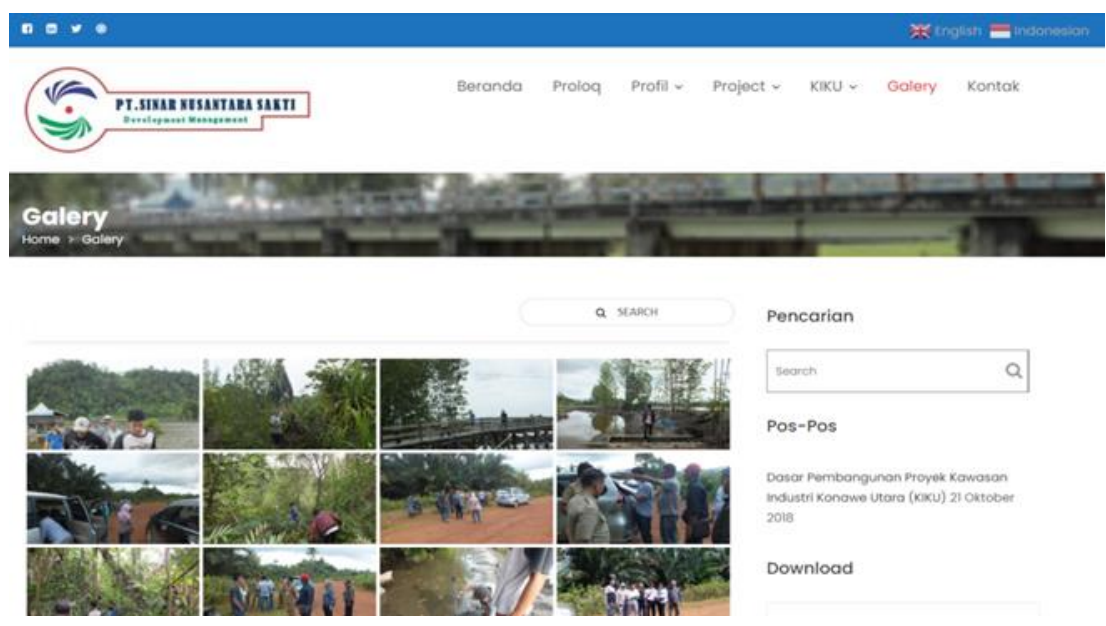

Pencarian

Gambar 17. Halaman Galery 
Jurnal Sistem Informasi dan Sistem Komputer,Vol.6, No.1, Januari 2021

ISSN: 2715-906X (Online)

10.51717/simkom.v6i1.54

Halaman ini memuat gallery photo kegiatan perusahaan yang berkaitan dengan survey lokasi produksi, dan pelabuhan.

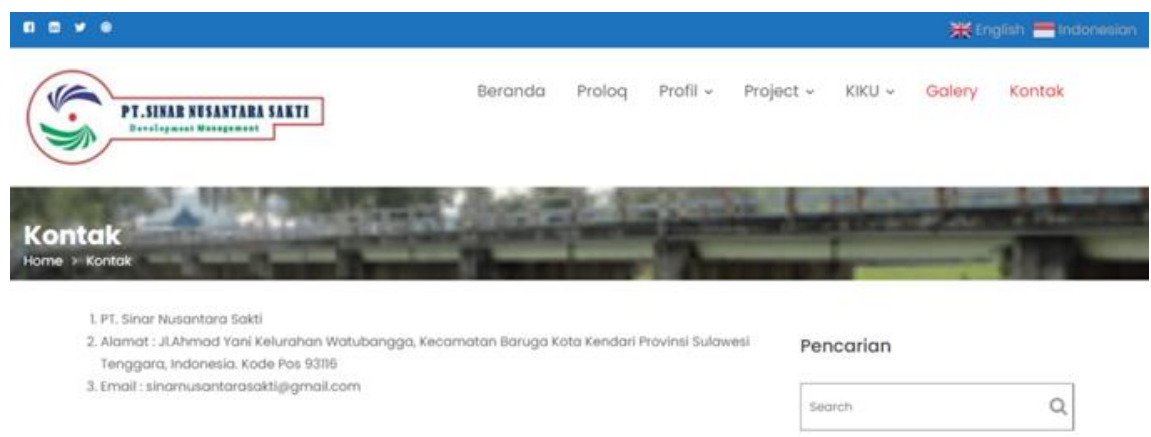

Gambar 18. Halaman Kontak

Halaman ini memuat informasi tentang alamat perusahaan, email, dan kontak yang dapat dihubungi oleh masyarakat untuk mendapatkan informasi perusahaan.

\section{Kesimpulan dan Saran}

\subsection{Kesimpulan}

Berdasarkan penelitian yang dilakukan terhadap sistem informasi company profile PT Sinar Nusantara sakti berbasis web menggunakan wordpress dapat disimpulkan:

1) Menghasilkan sistem informasi company profile berbasis web yang dapat digunakan untuk menyampaikan informasi terkait perusahaan secara global tanpa dibatasi oleh ruang dan waktu.

2) Hasil pengembangan system informasi company profil berbasis web dapat dimanfaatkan oleh PT. Sinar Nusantara Sakti untuk menyajikan profil perusahaan dan dapat dimanfaatkan oleh masyarakat untuk mendapatkan informasi.

\section{Daftar Pustaka}

[1] N. Q. Oktaviyanti, Perancangan Company Profile Sebagai Media Promosi, vol. 10, no. 2. 2018 .

[2] M. Bagir, "Rancang Bangun Website Company Profile Pada Newton Vintage Store Surabaya," 2017.

[3] P. Palcomtech, "Rancang Bangun Website Company Profile Pada Pt . Parahyangan Dwi Karya," 2018.

[4] A. Mayangsari and U. Khabibah, "Perancangan Dan Pembuatan Company Profile Berbasis Website Dengan Menggunakan Wordpress Sebagai Media Promosi B2B Di Super Kitchen Mojokerto," Jab J. Apl. Bisnis, pp. 153-159, 2017.

[5] Jogiyanto, Analisis dan Desain Sistem Informasi Pendekatan terstruktur. Yogyakarta: Andi. Offset, 1991.

[6] Jogiyanto H.M, Analisis dan Desain Informasi. Yogyakarta: Andi, 2005.

[7] Mustakini, Sistem Informasi Teknologi. Yogyakarta: Andi Offset, 2009.

[8] Yustini, Konsep Sistem Informasi. Yogyakarta: Andi, 2012.

[9] Fathansyah, Basis Data. Bandung: Informatika, 2012. 
Jurnal Sistem Informasi dan Sistem Komputer,Vol.6, No.1, Januari 2021

ISSN: 2715-906X (Online)

dol $10.51717 /$ simkom.v6i1.54

[10] Sutarman, Pengantar Teknologi Informasi. Jakarta: Bumi Aksara, 2012.

[11] Hartono, Analisis \& Desain Sistem Informasi. Yogyakarta: Andi, 1999.

[12] Agus Mulyanto, Sistem Informasi Konsep dan Aplikasi. Yogyakarta: Pustaka. Pelajar, 2009.

[13] Maimunah, L. Sunarya, and Nina Larasati, "Media Company Profile Sebagai Sarana," vol. 5, no. 40, pp. 281-301, 2012.

[14] L. Sunarya, R. Radiyanto, and E. Susanti, "Enriching Company Profile Sebagai Penunjang Media Informasi Dan Promosi Pada Perguruan Tinggi Raharja," CCIT J., vol. 7, no. 1, pp. 77-93, 2013, doi: 10.33050/ccit.v7i1.172.

[15] A. Z. dan S. C. Winarno, Edy, Panduan Lengkap Berinternet. Jakarta: PT Elex Media Komputindo, 2015.

[16] Arikunto, Prosedur Penelitian. Jakarta: Rineka Cipta, 1996.

[17] R. . Wahono, Aspek dan Kriteria Penilaian Media Pembelajaran. omiSatriaWohono.Net, 2006.

[18] C Kustandi, Media Pembelajaran Manual dan Digital. Bogor: Ghalia Indonesia, 2011. 